\title{
Association between Beta Adrenergic Receptor Polymorphism and Ischemic Stroke: A Meta-Analysis
}

\author{
Amit Kumar, Manya Prasad, Pradeep Kumar, Arun Kumar Yadav, Awadh Kishor Pandit, Prachi Kathuria \\ Department of Neurology, All India Institute of Medical Sciences, New Delhi, India
}

Background and Purpose The purpose of this meta-analysis was to determine the precise association between beta-2 adrenergic receptor ( $\beta 2 A R$ ) polymorphism and Ischemic stroke. Methods Published case control studies on association between $\beta 2 A R$ and ischemic stroke were searched from electronic databases. Pooled Odds ratio and 95\% Confidence interval were calculated by using software RevMan version 5.2.

Results A total of three studies involving 1,642 cases and 1,673 controls, which were published from 2007 to 2014, were subjected to meta-analysis for allelic association and 518 cases and 510 controls for genotypic association. Pooled analysis of two studies for genotypic association suggested that subjects carrying GIn27Glu polymorphism of $\beta 2 A R$ had an increased risk for Ischemic stroke under recessive model (OR 2.09; $95 \% \mathrm{Cl} ; 1.20$ to 3.64 ) and under dominant model (OR 1.47; $95 \% \mathrm{Cl} 1.14$ to 1.90). Pooled analysis of three studies for allelic association showed a significantly higher Glu27 allele of $\beta 2 A R$ in the patients with ischemic stroke (OR 1.58; 95\% Cl; 1.38 to 1.81 ).

Conclusions The present meta-analysis suggests that GIn27Glu polymorphism of $\beta 2 A R$ gene is associated with increased risk for ischemic stroke.

Keywords $\beta 2$-adrenergic receptor gene; $\beta 2 A R$; Ischemic stroke; Cerebral infarction; Polymorphism; Meta-analysis
Correspondence: Amit Kumar Room No-703, Department of Neurology Neurosciences Centre All India Institute of Medical Sciences Ansari Nagar, New Delhi-110029, India

Tel: +91-11-26594436

Fax: +91-11-26588663

E-mail: amits52003@gmail.com

Received: October 14, 2014

Revised: January 16, 2015

Accepted: January 24, 2015

The authors have no financial conflicts of interest.

\section{Introduction}

Stroke is the second common cause of death following ischemic heart disease. ${ }^{1}$ Stroke has accounted for nearly 5.7 million deaths globally and $87 \%$ of these deaths take place in low and middle income nations. ${ }^{2}$ Stroke is a multi-factorial disease and epidemiological and animal studies have robustly recommended genetic influences in the pathogenesis of ischemic stroke. ${ }^{3}$ The genetic influences are probably polygenic whereby multiple genes exert a small influence or risk on phenotype. Beta adrenergic receptors are members of a family of receptors known as G- protein coupled receptors (GPCR) and have a seven membrane spanning domain structure, an extracellular amino terminus, three intracellular and three extracellular loops, and an in- tracellular carboxyl terminus. ${ }^{4}$ These are receptors for neurohormone epinephrine and nor-epinephrine.

Several mechanisms contribute to loss of receptor activity including uncoupling of the receptor from adenylyl cyclase activity, internalization of the receptor and phosphorylation of internalized receptors. ${ }^{5}$ Several studies support the role of cyclic Adenosine Monophosphate (cAMP) in atherogenesis by modulating the function of vascular endothelium, the production of reactive oxygen species, the recruitment of circulating monocytes to the artery wall and their differentiation into macrophages-foam cells, by controlling the expression of pro-and anti-inflammatory interleukin, and regulating serum level of triglycerides and cholesterol. ${ }^{6,7}$ CAMP is also a possible target for prevention and treatment of atherosclerosis. ${ }^{6}$ The major non-synonymous SNPs of $\beta 2 \mathrm{AR}$ 
have been recognized at nucleotides $46(\mathrm{~A}>\mathrm{G})(\mathrm{rs} 1042713)$ and $79(\mathrm{C}>\mathrm{G})$ (rs1042714) causing changes in amino acid residues at position 16 (Arg $>$ Gly) and 27 (Gln $>\mathrm{Glu}$ ) of the amino terminus respectively of the fourth intracellular loop. An enhanced agonist-mediated receptor down-regulation for the Gly16 variant of $\beta 2 A R$ and a resistance to down-regulation for the Glu27 variant of $\beta 2 A R$ has been observed. ${ }^{8}$ It is hypothesized that due to the polymorphism in $\beta 2 \mathrm{AR}$, functional alteration in the receptor function occurs which influences a certain intermediate mechanism for the predisposition of cardiovascular and cerebrovascular diseases. ${ }^{9}$ We conducted a meta-analysis with available published studies to precisely determine the association of $\beta 2 A R$ with ischemic stroke in order to offer early diagnosis of the susceptible subjects.

\section{Methods}

\section{Literature search}

PubMed database was comprehensively searched from 2007 to 2014 to identify all relevant studies. The following search keywords were applied: 'BAR' OR 'BAR gene variant' OR $\beta 2 A R$, 'Beta-adrenergic receptor' OR 'Beta adrenergic receptor polymorphism' AND 'cerebral infarction' OR 'cerebrovascular accident' OR 'Ischemic stroke' OR 'brain infarction.'

\section{Criteria for considering the studies}

Inclusion criteria: (i) Case control study studying the association between $\beta 2 \mathrm{AR}$ polymorphism and stroke; (ii) Studies published in English language with full text; (iii) Stroke Confirmed by MRI or CT. Exclusion Criteria: (i) Studies other than case control design; (ii) Studies did not report genotypic and allelic frequencies; (iii) Duplicate publication.

\section{Selection of relevant articles}

Two investigators (AK and MP) independently evaluated the title, abstracts and search terms for eligibility based on the predetermined selection criteria. All Discrepancies were resolved after rechecking the source papers and further discussion among the two authors.

\section{Data extraction}

The relevant data from each study were independently extracted by two reviewers (AK and MP) using a standardized, structured form including first author's name, year of publication, country, genotyping method, no. of cases and controls and frequency distribution of genotype and allele.

\section{Results}

\section{Search results}

The literature search through PubMed yielded eight relevant publications. We screened through our inclusion and exclusion criteria. Two studies were excluded because they did not meet the inclusion criteria for study design (they were cohort studies). Two more studies were excluded because they studied another gene polymorphism and one study was excluded for being a pharmacogenetic study. One study ${ }^{10}$ did not report the genotype frequency in cases and controls. We requested for the genotype data for this study twice through email. However, we did not receive any reply from them. Therefore, this study could not be included for genotypic data meta-analysis. This study has reported the allelic frequency. Two studies ${ }^{11,12}$ reported the genotypic data, and therefore were included for genotypic association meta-analysis. One study ${ }^{12}$ reported deviation from Hardy Weinberg Equilibrium (HWE) in controls. Allelic data was reported in another study. ${ }^{10} \mathrm{~A}$ total three studies were included for allelic association

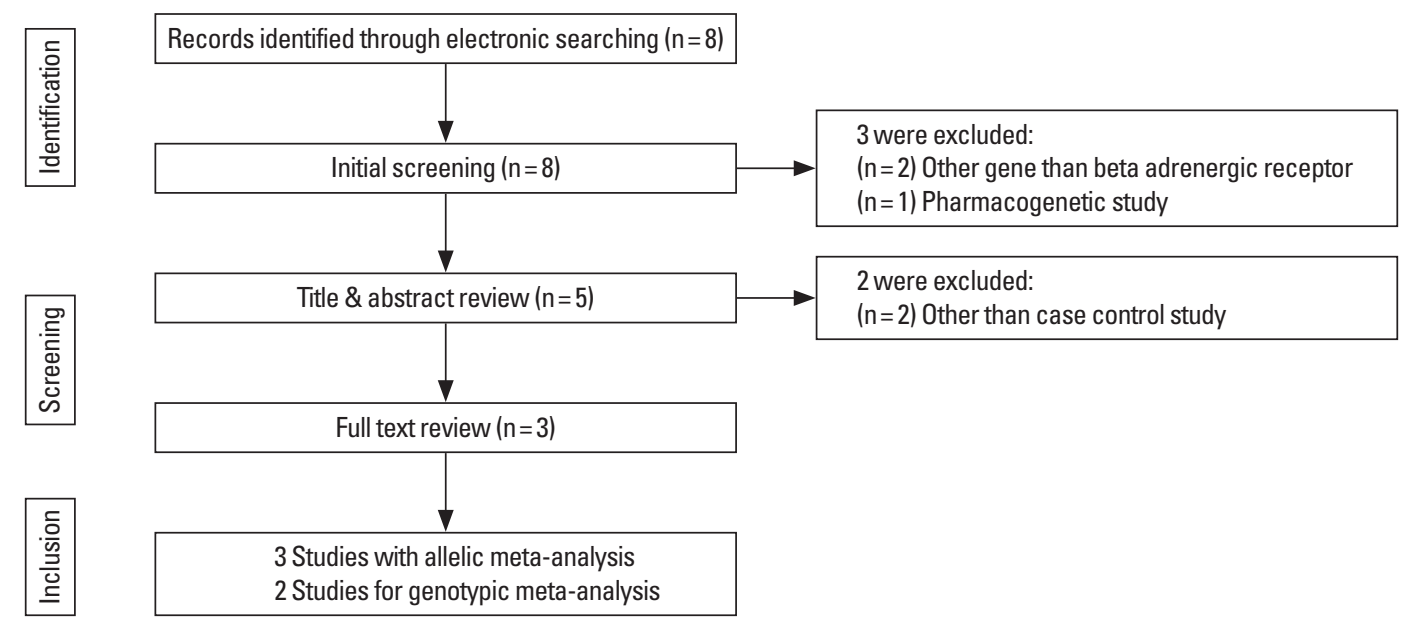

Figure 1. Flow diagram of the selection of studies and specific reasons for exclusion from the present meta-analysis. 
meta-analysis. Search results were also given in Flow Diagram (Figure 1).

\section{Meta-analysis results}

The study characteristics, which are included in the present meta-analysis, are described in Table 1 . A total of three studies involving 1,642 cases and 1,673 controls, which were published from 2007 to 2014, were subjected to meta-analysis for allelic association and 518 cases and 510 controls for genotypic association. Meta-analysis results did not show a significant association between Arg16Gly polymorphism of $\beta 2 \mathrm{AR}$ and ischemic stroke when assuming either recessive model of inheritance (OR 1.20; 95\% CI, 0.92 to 1.56 ) (Figure 2A) or dominant model of inheritance (OR 1.14; 95\% CI, 0.68 to 1.91) (Figure 2B). The allelic association also did not show statistically significant association between Arg16Gly polymorphism of $\beta 2 \mathrm{AR}$ and the risk of ischemic stroke (OR 1.04; 95\% CI, 0.85 to 1.28) (Figure 2C). Metaanalysis results did show a significant association between Gln27Glu polymorphism of $\beta 2 \mathrm{AR}$ and ischemic stroke when assuming either recessive model of inheritance (OR, 2.09; 95\% CI, 1.20 to 3.64) (Figure 3A) or the dominant model of inheritance (OR, 1.47; 95\% CI, 1.14 to 1.90) (Figure 3B). A significant allelic association was observed between Gln27Glu polymorphism of $\beta 2 \mathrm{AR}$ and ischemic stroke (OR, 1.58; 95\% CI, 1.38 to 1.81 ) (Figure 3C).

\section{Discussion}

The present meta-analysis was conducted to determine the precise estimation of association between polymorphism of $\beta 2 A R$ and risk of ischemic stroke. Several studies have shown an independent association of Gln27Glu polymorphism of $\beta 2 \mathrm{AR}$ gene number of diseases like obesity, ${ }^{13,14}$ dyslipidemia, ${ }^{14}$ myocardial infarction, ${ }^{15}$ and diabetes. ${ }^{16}$ Thus, Gln27Glu polymorphism of $\beta 2 A R$ has been suggested to be an independent risk factor for cardiovascular diseases and cerebrovascular diseases. ${ }^{17,18}$ Our meta-analysis suggests a significant association of Gln27Glu polymorphism of $\beta 2 A R$ with ischemic stroke. Our results are in agreement with earlier published study. ${ }^{12}$ However, two prospective cohort studies ${ }^{19,20}$ failed to show a significant association of $\beta 2 A R$ variant with the incidence of stroke. A prospective cohort study including 25,225 women showed that the different haplotypic combination of beta receptor gene variant did not affect the incidence of ischemic stroke in women..$^{20}$ Another cohort study reported from same population which included a total of 808 black and 4,441 white participants failed to find significant association of $\beta 2$ AR genotypic with risk of ischemic stroke and combined cardiovascular outcome. ${ }^{19}$ These two prospective cohort studies

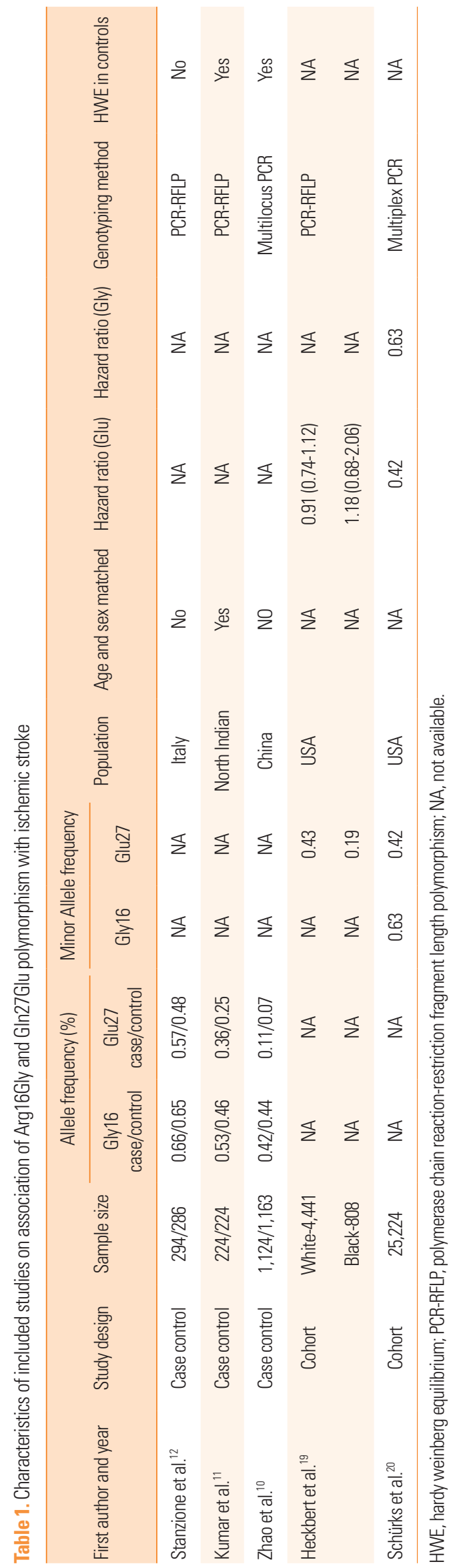

140 http://j-stroke.org 
Recessive model

\begin{tabular}{|c|c|c|c|c|c|c|c|c|c|}
\hline \multirow{2}{*}{$\begin{array}{l}\text { Study } \\
\text { Kumar A } 2014\end{array}$} & \multicolumn{2}{|c|}{$\begin{array}{l}\text { Cases } \\
\text { Gly/Gly Total }\end{array}$} & \multicolumn{2}{|c|}{$\begin{array}{l}\text { Control } \\
\text { Gly/Gly Total }\end{array}$} & \multirow{2}{*}{$\frac{\text { Weight }}{31.9 \%}$} & \multirow{2}{*}{$\begin{array}{c}\begin{array}{c}\text { Odds Ratio } \\
\text { M-H, Fixed, } 95 \% \mathrm{Cl}\end{array} \\
1.46[0.94,2.28]\end{array}$} & \multicolumn{3}{|c|}{$\begin{array}{c}\text { Odds Ratio } \\
\text { M-H, Fixed, } 95 \% \mathrm{Cl}\end{array}$} \\
\hline & 59 & 224 & 44 & 224 & & & & & \\
\hline Stanzione R 2007 & 136 & 294 & 127 & 286 & $68.1 \%$ & $1.08[0.78,1.49]$ & & & \\
\hline Total $(95 \% \mathrm{Cl})$ & & 518 & & 510 & $100.0 \%$ & $1.20[0.92,1.56]$ & & & \\
\hline Total & 195 & & 171 & & & & & & \\
\hline $\begin{array}{l}\text { Heterogeneity: Chi } \\
\text { Test for overall effe }\end{array}$ & $\begin{array}{l}18, \mathrm{df}= \\
=1.36\end{array}$ & $\begin{array}{l}1(P= \\
=0.1\end{array}$ & $.28) ;\left.\right|^{2}=$ & $15 \%$ & & & 0.01 & $\begin{array}{lll}0.1 & 1 & 10 \\
\text { Protective } & \text { Risk }\end{array}$ & 100 \\
\hline
\end{tabular}

A

Dominant model

\begin{tabular}{|c|c|c|c|c|c|c|c|c|c|}
\hline Study & $\begin{array}{r}\text { Case } \\
\text { Arg/Gly }\end{array}$ & $\begin{array}{l}\mathbf{s} \\
\text { Total }\end{array}$ & $\begin{array}{r}\text { Contr } \\
\text { Arg/Gly }\end{array}$ & Total & Weight & $\begin{array}{l}\text { Odds Ratio } \\
\text { M-H, Random, } 95 \% \mathrm{Cl}\end{array}$ & & $\begin{array}{l}\text { Odds Ratio } \\
\text { M-H, Random, } 95 \% \mathrm{Cl}\end{array}$ & \\
\hline Kumar A 2014 & 177 & 224 & 161 & 224 & $51.3 \%$ & $1.47[0.95,2.27]$ & & & \\
\hline Stanzione R 2007 & 249 & 294 & 247 & 286 & $48.7 \%$ & $0.87[0.55,1.39]$ & & & \\
\hline Total $(95 \% \mathrm{Cl})$ & & 518 & & 510 & $100.0 \%$ & $1.14[0.68,1.91]$ & & & \\
\hline Total & 426 & & 408 & & & & & & \\
\hline \multicolumn{7}{|c|}{$\begin{array}{l}\text { Heterogeneity: } \text { Tau }^{2}=0.08 ; \mathrm{Chi}^{2}=2.60, \mathrm{df}=1(\mathrm{P}=0.11) ; \mathrm{I}^{2}=62 \% \\
\text { Test for overall effect: } Z=0.51(\mathrm{P}=0.61)\end{array}$} & 0.01 & $\begin{array}{lll}0.1 & 10 \\
\text { Protective Risk }\end{array}$ & 100 \\
\hline
\end{tabular}

B

Allelic association

\begin{tabular}{|c|c|c|c|c|c|c|c|c|c|c|}
\hline Study & $\begin{array}{r}\text { Case } \\
\text { Gly16 } \\
\end{array}$ & Total & $\begin{array}{l}\text { Contr } \\
\text { Gly16 }\end{array}$ & $\begin{array}{l}\text { rol } \\
5 \text { Total }\end{array}$ & Weight & $\begin{array}{c}\text { Odds Ratio } \\
\text { M-H, Random, } 95 \% \mathrm{Cl}\end{array}$ & & $\begin{array}{r}\text { Odds } \\
\text { M-H, Rand }\end{array}$ & $\begin{array}{l}\text { s Ratio } \\
\text { dom, } 95 \% \mathrm{Cl}\end{array}$ & \\
\hline Kumar A 2014 & 236 & 448 & 205 & 448 & $27.4 \%$ & $1.32[1.01,1.72]$ & & & $=$ & \\
\hline Nan Zhao 2012 & 944 & 2248 & 1023 & 2326 & $43.2 \%$ & $0.92[0.82,1.04]$ & & & & \\
\hline Stanzione R 2007 & 385 & 588 & 374 & 572 & $29.4 \%$ & $1.00[0.79,1.28]$ & & & & \\
\hline Total $(95 \% \mathrm{Cl})$ & & 3284 & & 3346 & $100.0 \%$ & $1.04[0.85,1.28]$ & & & $\boldsymbol{\gamma}$ & \\
\hline Total & 1565 & & 1602 & & & & & & & \\
\hline \multicolumn{7}{|c|}{$\begin{array}{l}\text { Heterogeneity: } \operatorname{Tau}^{2}=0.02 ; \mathrm{Ch}^{2}=6.01, \mathrm{df}=2(\mathrm{P}=0.05) ; \mathrm{I}^{2}=67 \% \\
\text { Test for overall effect: } Z=0.41(P=0.68)\end{array}$} & 0.01 & $\begin{array}{l}0.1 \\
\text { Protective }\end{array}$ & 1 Risk & 100 \\
\hline
\end{tabular}

Figure 2. Forest plot of odds ratio (ORs) for association of polymorphism at Arg16Gly (SNP $46 \mathrm{~A}>\mathrm{G}$ ) position of beta-2 adrenergic receptor gene with ischemic stroke.

in which significant associations were not observed, were reported from the American population ${ }^{19,20}$ while the other two studies, ${ }^{11,12}$ which showed the significant genotypic association, were reported from India and Italy. As the prevalence of genetics variants often varies among populations, ${ }^{19}$ this could explain the discrepancy of association of Gln27Glu polymorphism of $\beta 2 \mathrm{AR}$ and ischemic stroke across the studies. A case control study reported by Zhao et al. ${ }^{10}$ in Chinese population showed significant allelic association between Glu allele of $\beta 2 A R$ and risk of ischemic stroke (Figure 2C). In all the published case control studies (three), ${ }^{10-12}$ frequency of the risk allele (Glu27) was higher in cases as compared to controls. Our meta-analysis of allelic association including three studies with the risk allele versus protective allele suggested significantly higher risk of ischemic stroke with Glu27 allele. The meta-analysis for genotypic association including two studies also suggested a significant association between Gln27Glu polymorphism and risk of ischemic stroke under both dominant model and recessive model of inheritance.

\section{Limitations of study}

Some limitations exist in the present study, which may have affected the results of meta-analysis. The haplotype analysis was not done which plays a crucial role for association studies of complex diseases. The interaction between gene and environment and gene-gene interaction was not studied in this meta-analysis. Controls were selected from the hospital, which may have lead to the selection bias. Multivariate analysis for adjusting the several confounding factors that could have an effect on results was not performed as individual data from each study was not available. Studies were reported from different ethnic population and devi- 
Recessive model

\begin{tabular}{|c|c|c|c|c|c|c|c|c|c|c|}
\hline \multirow{2}{*}{$\frac{\text { Study or Subgroup }}{\text { Kumar A } 2014}$} & \multicolumn{2}{|c|}{$\begin{array}{l}\text { Cases } \\
\text { Glu/Glu Total }\end{array}$} & \multicolumn{2}{|c|}{$\begin{array}{l}\text { Control } \\
\text { Glu/Glu Total }\end{array}$} & \multirow{2}{*}{$\frac{\text { Weight }}{37.7 \%}$} & \multirow{2}{*}{$\begin{array}{c}\text { Odds Ratio } \\
\text { M-H, Random, } 95 \% \mathrm{Cl} \\
3.01[1.54,5.85]\end{array}$} & \multicolumn{4}{|c|}{$\begin{array}{l}\text { Odds Ratio } \\
\text { M-H, Random, } 95 \% \mathrm{Cl}\end{array}$} \\
\hline & 35 & 224 & 13 & 224 & & & & & $\rightarrow$ & \\
\hline Stanzione R 2007 & 123 & 294 & 86 & 286 & $62.3 \%$ & $1.67[1.19,2.36]$ & & & & \\
\hline Total $(95 \% \mathrm{Cl})$ & & 518 & & 510 & $100.0 \%$ & $2.09[1.20,3.64]$ & & & & \\
\hline Total & 158 & & 99 & & & & & & & \\
\hline \multicolumn{7}{|c|}{$\begin{array}{l}\text { Heterogeneity: } \operatorname{Tau}^{2}=0.10 ; \mathrm{Chi}^{2}=2.35, \mathrm{df}=1(\mathrm{P}=0.12) ; \mathrm{I}^{2}=58 \% \\
\text { Test for overall effect: } Z=2.59(P=0.010)\end{array}$} & 0.01 & $\begin{array}{l}0.1 \\
\text { Protective }\end{array}$ & Risk & 100 \\
\hline
\end{tabular}

Dominant model

\begin{tabular}{|c|c|c|c|c|c|c|c|c|c|c|}
\hline Study & $\begin{array}{r}\text { Case } \\
\text { GIn/Glu } \\
\end{array}$ & S Total & $\begin{array}{r}\text { Contr } \\
\text { Gln/Glu } \\
\end{array}$ & $\begin{array}{l}\text { ol } \\
\text { Total }\end{array}$ & Weight & $\begin{array}{c}\text { Odds Ratio } \\
\text { M-H, Fixed, } 95 \% \mathrm{Cl}\end{array}$ & \multicolumn{4}{|c|}{$\begin{array}{c}\text { Odds Ratio } \\
\text { M-H, Fixed, } 95 \% \mathrm{Cl}\end{array}$} \\
\hline Kumar A 2014 & 126 & 224 & 98 & 224 & $44.5 \%$ & $1.65[1.14,2.40]$ & & & & \\
\hline Stanzione R 2007 & 212 & 294 & 189 & 286 & $55.5 \%$ & $1.33[0.93,1.89]$ & & & & \\
\hline Total $(95 \% \mathrm{Cl})$ & & 518 & & 510 & $100.0 \%$ & $1.47[1.14,1.90]$ & & & $\boldsymbol{\gamma}$ & \\
\hline Total & 338 & & 287 & & & & & & & \\
\hline $\begin{array}{l}\text { Heterogeneity: Chi } \\
\text { Test for overall effe }\end{array}$ & $\begin{array}{l}0.70, \mathrm{df}= \\
Z=2.95\end{array}$ & $\begin{array}{l}1(P= \\
P=0.0\end{array}$ & $\begin{array}{l}\text { (40); }\left.\right|^{2}= \\
\text { 13) }\end{array}$ & $0 \%$ & & & 0.01 & $\begin{array}{l}0.1 \\
\text { Protective }\end{array}$ & Risk 10 & 100 \\
\hline
\end{tabular}

B

\begin{tabular}{|c|c|c|c|c|c|c|c|c|c|c|}
\hline Study & $\begin{array}{r}\text { Case } \\
\text { Glu27 } \\
\end{array}$ & Total & $\begin{array}{l}\text { Contr } \\
\text { Glu27 } \\
\end{array}$ & Total & Weight & $\begin{array}{l}\text { Odds Ratio } \\
\text { M-H, Fixed, } 95 \% \mathrm{Cl}\end{array}$ & & $\begin{array}{r}\text { Odds } \\
\text { M-H, Fixe }\end{array}$ & $\begin{array}{l}\text { Ratio } \\
\text { d, } 95 \% \mathrm{Cl}\end{array}$ & \\
\hline Kumar A 2014 & 161 & 448 & 112 & 448 & $21.5 \%$ & $1.68[1.26,2.24]$ & & & - & \\
\hline Nan Zhao 2012 & 247 & 2248 & 162 & 2326 & $42.5 \%$ & $1.65[1.34,2.03]$ & & & 듭 & \\
\hline Stanzione R 2007 & 335 & 588 & 275 & 572 & $36.0 \%$ & $1.43[1.13,1.80]$ & & & 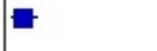 & \\
\hline Total $(95 \% \mathrm{Cl})$ & & 3284 & & 3346 & $100.0 \%$ & $1.58[1.38,1.81]$ & & & $\bullet$ & \\
\hline Total & 743 & & 549 & & & & & & & \\
\hline \multicolumn{7}{|c|}{$\begin{array}{l}\text { Heterogeneity: } C^{2}=1.06, d f=2(P=0.59) ;\left.\right|^{2}=0 \% \\
\text { Test for overall effect: } Z=6.57(P=0.00001)\end{array}$} & 0.01 & $\begin{array}{ll}0.1 & 1 \\
\text { Protective }\end{array}$ & Risk & 100 \\
\hline
\end{tabular}

Figure 3. Forest plot of odds ratio (ORs) for association of polymorphism at Gln27Glu (79C > G) position of beta-2 adrenergic receptor with ischemic stroke.

ation from HWE equilibrium in control subjects in one study included in this meta-analysis may account for the heterogeneity.

\section{Conclusion}

The present study provides preliminary evidence to support the view that carrier of Gln27Glu polymorphism of $\beta 2 A R$ demonstrates an increase in risk of ischemic stroke on the basis of meta-analysis of case control studies. Furthermore, well designed larger prospective cohort studies are required to validate this finding and to provide a higher level of evidence. The underlying molecular causal pathways that confer susceptibility to ischemic stroke are warranted to be established.

\section{References}

1. Strong K, Mathers C, Bonita R. Preventing stroke: saving lives around the world. Lancet Neurol 2007;6:182-187.

2. Feigin VL, Forouzanfar MH, Krishnamurthi R, Mensah GA, Connor M, Bennett DA, et al. Global and regional burden of stroke during 1990-2010: findings from the Global Burden of Disease Study 2010. Lancet 2014;383:245-254.

3. Hassan A, Markus HS. Genetics and ischaemic stroke. Brain 2000; 123:1784-1812.

4. Nakashima A, Takeuchi $H$, Imai $T$, Saito $H$, Kiyonari $H$, Abe T, et al. Agonist-independent GPCR activity regulates anteriorposterior targeting of olfactory sensory neurons. Cell 2013; 154:1314-1325.

5. Chung KY, Rasmussen SG, Liu T, Li S, DeVree BT, Chae PS, et 
al. Conformational changes in the $\mathrm{G}$ protein $\mathrm{Gs}$ induced by the $\beta 2$ adrenergic receptor. Nature 2011;477:611-615.

6. Fantidis P. The role of intracellular 3'5'-cyclic adenosine monophosphate (cAMP) in atherosclerosis. Curr Vasc Pharmacol 2010; 8:464-472.

7. Zhang F, Steinberg SF. S49G and R389G polymorphisms of the $\beta_{1}$-adrenergic receptor influence signaling via the cAMPPKA and ERK pathways. Physiol Genomics 2013;45:1186-1192.

8. Green SA, Turki J, Innis M, Liggett SB. Amino-terminal polymorphisms of the human beta 2-adrenergic receptor impart distinct agonist-promoted regulatory properties. Biochemistry 1994;33:9414-9419.

9. Leineweber K. Beta-adrenergic receptor polymorphism in human cardiovascular disease. Ann Med 2004;36(Suppl 1):64-69.

10. Zhao N, Liu X, Wang Y, Liu X, Li J, Yu L, et al. Association of inflammatory gene polymorphisms with ischemic stroke in a Chinese Han population. J Neuroinflammation 2012;9:162.

11. Kumar A, Tripathi M, Srivastava MV, Vivekanandhan S, Prasad $K$. Relationship between polymorphisms in beta -2 adrenergic receptor gene and ischemic stroke in North Indian Population: a hospital based case control study. BMC Res Notes 2014;7: 396.

12. Stanzione R, Di Angelantonio E, Evangelista A, Barbato D, Marchitti S, Zanda B, et al. Beta2-adrenergic receptor gene polymorphisms and risk of ischemic stroke. Am J Hypertens 2007;20:657-662.

13. Lange LA, Norris JM, Langefeld CD, Nicklas BJ, Wagenknecht LE, Saad MF, et al. Association of adipose tissue deposition and beta-2 adrenergic receptor variants: the IRAS family study. Int $J$ Obes (Lond) 2005;29:449-457.
14. Large V, Hellström L, Reynisdottir S, Lönnqvist F, Eriksson P, Lannfelt L, et al. Human beta- 2 adrenoceptor gene polymorphisms are highly frequent in obesity and associate with altered adipocyte beta-2 adrenoceptor function. J Clin Invest 1997; 100:3005-3013.

15. Yilmaz A, Kaya MG, Merdanoglu U, Ergun MA, Cengel A, Menevse S. Association of beta- 1 and beta- 2 adrenergic receptor gene polymorphisms with myocardial infarction. J Clin Lab Anal 2009;23:237-243.

16. Carlsson M, Orho-Melander M, Hedenbro J, Groop LC. Common variants in the beta2-(Gln27Glu) and beta3-(Trp64Arg)-adrenoceptor genes are associated with elevated serum NEFA concentrations and type II diabetes. Diabetologia 2001;44: 629-636.

17. Barbato E, Berger A, Delrue L, Van Durme F, Manoharan G, Boussy T, et al. GLU-27 variant of beta2-adrenergic receptor polymorphisms is an independent risk factor for coronary atherosclerotic disease. Atherosclerosis 2007;194:e80-e86.

18. Sotoodehnia N, Siscovick DS, Vatta M, Psaty BM, Tracy RP, Towbin JA, et al. Beta2-adrenergic receptor genetic variants and risk of sudden cardiac death. Circulation 2006;113:1842-1848.

19. Heckbert SR, Hindorff LA, Edwards KL, Psaty BM, Lumley T, Siscovick DS, et al. Beta2-adrenergic receptor polymorphisms and risk of incident cardiovascular events in the elderly. Circulation 2003;107:2021-2024.

20. Schürks M, Kurth T, Ridker PM, Buring JE, Zee RY. Association between polymorphisms in the beta2-adrenergic receptor gene with myocardial infarction and ischaemic stroke in women. Thromb Haemost 2009; 101:351-358. 